\title{
Tax Treatment on the Amortization Expenses of Goodwill Arising from Acquisition as Deductible Expenses to Gross Income in the Calculation of Taxable Income
}

\author{
Alfian Dovi Pradana ${ }^{1 *}$, Ning Rahayu ${ }^{1}$ \\ ${ }^{1}$ Faculty of Economics and Business, Universitas Indonesia, Depok 16424, Indonesia \\ *alfiandovipradana@gmail.com
}

\begin{abstract}
Tax audit by the Directorate General of Taxation (DJP) on PT A for several years has revealed legal uncertainty on the amortization expenses of goodwill of PT A for tax purpose. Such uncertainty is reflected in a number of Tax audit result Assessment Letters revealing inconsistent corrections on the amortization expenses of goodwill of PT A. The argumentations used by the DJP in revealing such corrections also seem contradictory to the applicable accounting and taxation provisions. With regard to it, this research is aimed at analyzing the argumentation used by the DJP in applying tax treatment on the amortization expenses of goodwill arising from acquisition if tested using the applicable accounting and taxation provisions. In addition, this research is also aimed at analyzing tax treatment on the amortization expenses of goodwill of PT A applied by DJP if seen from the legal certainty principle. The approach used in this research is qualitative approach. The data collecting techniques used are literature study and field study through in-depth interviews with stakeholders as key informants. Based on existing findings and discussions, the argumentations used by the DJP in applying tax treatment on the amortization expenses of goodwill of PT A had not been in accordance with the applicable accounting and taxation provisions. In addition, tax treatment on the amortization expenses of goodwill of PT A applied by the DJP also had not entirely fulfilled the legal certainty principle.
\end{abstract}

Keywords: Amortization; Goodwill; Acquisition; Deductible Expenses; Income Tax.

\section{INTRODUCTION}

The corrections made by tax auditors on PT A were related to the amortization expenses of goodwill arising from acquisition in 2003, 2004, and 2006. The aforementioned corrections to amortization expenses were performed in fiscal years 2008, 2009, 2011, and 2013. These corrections seem different from the corrections in other audited fiscal years namely fiscal years 2007, 2010, and 2012 where the DJP did not correct the amortization expenses of goodwill of PT A. In this case there were inconsistent corrections by the DJP on the amortization expenses of goodwill of PT A. From table 1 can be seen the Income Tax audit results of PT A for several years.

Such inconsistent corrections had resulted in the occurrence of inconsistent tax treatment on the amortization expenses of goodwill of PT A as deductible expenses to gross income in calculating Taxable Income. In addition, this had also resulted in prolonged disputes between PT A and the DJP at the Indonesian Tax Court. In general, PT A was of the opinion that goodwill amortization expenses shall be deductible expenses to decrease Taxable Income. Such opinion of PT A was in accordance with Article 11 A of the Income Tax Law allowing goodwill amortization expenses as deductible expense. On the other hand, the DJP was of the opinion that the Goodwill of PT A should have been non-existent as in accordance with the 2004 revision to Indonesian Financial Accounting Standards (IFAS) No. 38, value surplus resulting from transactions between equities under common control should constitute the element of equity and might not be acknowledged as goodwill. The Different opinions between PT A and the DJP had resulted in inconsistent corrections in PT A, therefore clarity and legal certainty for both parties are required. Therefore, the aim of this research are first, analyzing the argumentations used by the DJP in applying tax treatment on the amortization expenses of goodwill arising from acquisition if tested using the applicable accounting and taxation provisions; second, analyzing tax treatment on the amortization expenses of goodwill of PT A applied by the DJP if seen from the legal certainty principle. 
Table.1. List of Annual Income Tax Audit Results of PT A

\begin{tabular}{ccc}
\hline No. & Fiscal Year & $\begin{array}{c}\text { corrections to the amortization } \\
\text { expenses of goodwill as the } \\
\text { result of acquisition }\end{array}$ \\
\hline 1. & 2007 & Corrections Not Available \\
\hline 2. & 2008 & Corrections Available \\
\hline 3. & 2009 & Corrections Available \\
\hline 4. & 2010 & Corrections Not Available \\
\hline 5. & $2011 \mathrm{z}$ & Corrections Available \\
\hline 6. & 2012 & Corrections Not Available \\
\hline 7. & 2013 & Corrections Available \\
\hline & & Source: PT A's Report.
\end{tabular}

\section{LITERATURE REVIEW}

For conducting analysis and discussion related to the argumentations of the DJP in providing tax treatment on the amortization expense of goodwill of PT A, there are a number of principal theories used, namely the theories of goodwill, tax audit, expenses, formal and material legal certainty principles as well as legal interpretation. Goodwill according is purchase value surplus above the identified net asset reasonable value ${ }^{1}$. Procedures for reducing the value of goodwill as intangible asset in many states can be done in 2 methods, namely through amortization and impairment test ${ }^{2}$. Both amortization and impairment of goodwill in the accounting world will be recorded as expenses commercially affecting the company's profits and losses.

Specifically, for taxation purpose, there are a number of conditions for particular expenses or costs to become deductible expenses to gross income for the calculation of Taxable Income. There are 2 conditions for the costs or expenses that may be deducted from the gross income for obtaining Taxable Income, namely: First, the Taxpayer has paid for particular costs or expenses that according to the laws and regulations may actually become deductible expenses to gross income; and second, the Taxpayer must be able to prove that the costs and expenses paid are actually allowed to become deductible expenses in the laws and regulations ${ }^{3}$. In addition, there are some conditions for costs or expenses to become company's expenditures are first, the costs paid clearly are not prohibited costs based on the provision of taxation regulations; second, the costs paid are costs for obtaining, collecting, and maintaining Taxable Income; third, the costs paid are not costs for the personal interests of the owner of income; fourth, the costs paid do not include the capitalized costs; and fifth, the costs paid are still in reasonable value $e^{4,5,6}$.

The implementation of tax collection in a state requires clear legal ground for guaranteeing legal certainty in tax collection ${ }^{7,5}$. Legal certainty in tax collection can be divided into 2, namely formal legal certainty and material legal certainty. Tax formal legal certainty shall be legal certainty related to procedures for applying or enforcing tax material law. Whereas tax material legal certainty shall be legal certainty related to the certainty on tax subject, tax object, and tax rate to be charged ${ }^{8}$. Creating legal certainty also requires correct and accurate legal interpretation that is in accordance with the purpose and objective of the drawing up of a law. Therefore, there are several types of legal interpretation that can be used, namely Grammatical Interpretation; Systematic or Logical Interpretation; Historical Interpretation; Teleological (Sociological) Interpretation; Comparative Interpretation; Anticipative and Futuristic Interpretation; Restrictive Interpretation; and Extensive Interpretation. Specifically, for discussion on legal interpretation in the disputes between PT A and the DJP, Grammatical Interpretation and Systematic or Logical Interpretation shall be used. Grammatical Interpretation shall be legal interpretation in a regulation using the terms or sentences used in daily language or legal language, whereas Systematic or Logical Interpretation shall be the interpretation of a regulation in relation to other regulations or laws seen systematically and comprehensively. This Systematic or Logical Interpretation may prevent the occurrence of legal interpretation beyond the applicable legal system or regulations ${ }^{9}$.

\section{RESEARCH METHOD}

The research approach used is qualitative approach in the form of case study with descriptive research type so that discussion on existing phenomena can be conducted and analyzed comprehensively ${ }^{10}$. The data collecting techniques used are literatures study and field study. In literatures study, data shall be collected by way of taking information from books, publications, journals, and regulations related to research. Further, for field study, data shall be collected by conducting in-depth interviews with the stakeholders competent in their respective fields and understanding the problems arising in this research (Key Informants). The informants to be interviewed in this research are: academicians, practitioners, DJP, and Tax Division in PT A. 


\section{RESULTS AND DISCUSSION}

The increasingly rapid technology development had forced PT A to perform business restructuring for maintaining its business continuity in Indonesia and to prepare itself in facing competitions with the competitors. For such purpose, the shareholders of PT A had agreed with the board of directors and the management of PT A to perform acquisition on all shares of PT D through 2 stages. The first stage was to perform acquisition on PT B that owned $45 \%$ shares of PT D in 2003, and the second stage was to perform acquisition on $25 \%$ shares of PT D owned by PT C in 2004. The aforementioned PT B and PT D acquisition activities had brought out goodwill to PT A. Thereafter for facilitating company control due to 100\% PT B and PT D ownership by PT A, PT B and PT D were merged into PT A in 2005. Such merger was conducted by using pooling of interest methods (book value) so that based on accounting there had not been any difference resulting in difference between the previous consolidated financial statements of PT A and the financial statements of PT A following merger. Thereby, in the financial statements of PT A following merger, the goodwill of PT A arising at the time of acquisition from a third party had been continuously existent up to 2014. The goodwill of PT B and PT D had also been amortized by PT A up to 2010, whereas following the year 2010 PT A has no longer been performing goodwill amortization.

In 2006, PT A also conducted business restructuring activity in the form of purchase of $5 \%$ shares of PT E from a party having no association relationship with PT A. Such purchase was conducted at the value above the identified reasonable net asset value of PT E, therefore, at the time those shares were purchased goodwill arose from PT E. This goodwill originating from PT E had also been amortized by PT A up to 2010, whereas following the year 2010 PT A had ceased activity of amortizing goodwill from PT E.

Based on the accounting provisions, the acquisition process conducted by PT A towards PT B, PT D, and PT E basically had created Goodwill to PT A. The goodwill originating from the aforementioned acquisition of PT B, PT D, and PT E can be analyzed using the goodwill theory and the IFAS 22. Pursuant to the goodwill theory, goodwill shall be formed in the event of purchase value surplus above the identified net asset reasonable value. In the transaction taking place at the time of acquisition of PT B, PT D, and PT E by PT A, the shares were also purchased above the identified net asset reasonable value so as to result in surplus in the form of goodwill. The goodwill of PT A originating from PT B was created in 2003 when PT A purchased $100 \%$ shares of PT B. The goodwill originating from PT D was created in 2004 when PT A purchased 25\% shares of PT D from a third party (PT C). Whereas the goodwill originating from PT E was created when PT A purchased 5\% shares of PT E from PT $\mathrm{F}$

Whereas the merger activity of PT A with PT B and PT D in 2005 resulting in the amalgamation of PT B and PT D into PT A basically should not delete the goodwill created during acquisition. This is because this business restructuring in the form of merger can be considered as permanent consolidation conducted by PT A to PT B and D. Through permanent consolidation, the assets and liabilities of PT B and PT D should be permanently presented in the financial statements of PT A for by law, the assets and liabilities of PT B and PT D had been transferred to PT A. The substance of the aforementioned goodwill actually had also been created not from merger but from a non-association third party at the time of acquisition. Thereby, the tax auditor's opinion using the provisions of the IFAS 38 and stating that the value difference of merger transaction of PT A with PT B and PT D was a difference that must be brought into the equity element was incorrect. Thereafter, with the existence of such goodwill, it should be reasonable for the goodwill amortization expenses in the tax calculation to state in the Income Tax Return of PT A.

In the taxation provisions, the goodwill of PT A actually had fulfilled the conditions to become deductible expense to gross income in calculating Taxable Income. This can be seen from the fulfilled requirements for particular expenses to become deductible expenses for taxation purpose, namely: first, the costs paid clearly are not prohibited costs based on the provision of taxation regulations; second, the costs paid are costs for obtaining, collecting, and maintaining Taxable Income; third, the costs paid are not costs for the personal interests of the owner of income; fourth, the costs paid do not include the capitalized costs; fifth, the costs paid are still in reasonable value; sixth, the Taxpayer has paid particular costs or expenses that based on the laws and regulations may become deductible expenses to gross income; and seventh, the Taxpayer is able to prove that the costs and charges paid are allowed to become deductible expenses based on the laws and regulations $\mathrm{s}^{3,4,5}$.

Whereas for the amortization expenses of goodwill from PT E, the tax auditor could not accept the argumentation of PT A stating that the aforementioned goodwill amortization expenses were the expense paid for obtaining, collecting, and maintaining Taxable Income. This was because according to the auditor, the goodwill occurred merely for obtaining dividends that were not the objects of income tax as regulated in article 4 paragraph (3) of the Income Tax Law and Article 13 of Government Regulation No. 94 year 2010. However, such auditor's opinion was weak. This was because based on the existing data, the objective and background of the occurrence of acquisition and merger in PT A would significantly affect the Taxable Income of PT A, namely first, the extremely rapid development of business type or business of PTA requires prompt and accurate strategic measures from PT A so as to result in PT A having to perform expansion with acquisition and merger; second, increasing the power 
competition with domestic and global competitors; third, increasing market share in Indonesia in the international sector; fourth, increasing synergy and development of commercial strategies of PT A in the line of business of PT A including its integration in product marketing; fifth, optimizing the financial structure of PT A; sixth, increasing cost efficiency in case of capital expenditure and operational activity; and seventh, building strong organization by optimizing human resources originating from outside PT A.

From the aforementioned data can be seen that the goodwill and the amortization expenses of goodwill of PT A were not merely for obtaining dividends but were having far broader benefit towards the Taxable Income of PT A. In addition, the dividends received by PT A from PT E only occurred once between 2006 and 2013, so that the matching cost against revenue principle also had not been fulfilled in the charging of goodwill amortization as expenses for obtaining dividends. Thereby, the amortization expenses of goodwill of PT A originating from PT E actually could be charged as deductible expenses to gross income for calculating Taxable Income.

The tax treatment applied by the DJP towards the amortization expenses of goodwill of PT A also had not fulfilled the legal certainty principle in the field of taxation. Legal certainty in the field of taxation can be seen from formal law certainty and material law certainty. In formal law certainty, the DJP had not acknowledged the financial statements of PT A that had been audited by the Independent Auditor. Whereas according to article 28 paragraph (7) of the General Tax Provisions and Procedures Law insofar as the bookkeeping of the taxpayer has followed the common bookkeeping procedures in Indonesia, namely the Indonesian Financial Accounting Standards (IFAS), such bookkeeping can be used as valid data for calculating Taxable Income unless determined otherwise in the laws and regulations. However, tax auditors had not observed article 28 paragraph (7) of the General Tax Provisions and Procedures Law so that the audited bookkeeping of PT A became uncertain to be used as basis for the calculation of Taxable Income. This was reflected from the unacknowledged goodwill formed in PT A so that the amortization expenses of goodwill of PT A also had not been acknowledged as deductible expenses to gross income in calculating Taxable Income.

In material law certainty, tax law certainty shall be tested through 3 matters namely first, certainty on tax subject, certainty on tax object, and certainty on the rate charged. Out of the three tests, the fulfillment of material law certainty on tax object had not been fulfilled. This was due to the different interpretations between PT A and the DJP related to the definition of costs or charges that cannot be considered as tax costs due to their use for obtaining non-taxable income as regulated in article 13 of Government Regulation No. 94 year 2010.

PT A and the DJP had different legal interpretations on article 13 of Government Regulation No. 94 year 2010 regulating the following:

"Non-deductible expenses and costs in determining the amount of Taxable Income for domestic Taxpayer and permanent establishment, shall include: a) costs for obtaining, collecting, and maintaining nontaxable income; which tax imposition shall be final; and/or imposed with tax based on the Net Income Calculation Norms as referred to in Article 14 of the Income Tax Law and the Special Calculation Norms as referred to in Article 15 of the Income Tax Law; b) Income Tax borne by employer.”

According to the tax auditor, all charges directly related to non-taxable income could not be used as deductible expenses to gross income in calculating Taxable Income. Therefore, the auditor had interpreted the relevant regulation grammatically. Whereas according to PT A, the aforementioned regulation must be interpreted logically and historically. With logical and historical interpretations, Article 13 of Government Regulation No. 94 could be seen comprehensively logically, and in inter-correlation with other regulations including the actual objective of the drawing up of the relevant article. If seen from the logical and historical interpretations, the actual objective of the relevant Article was to avoid the occurrence of shifting costs and expenses from the costs used for obtaining non-taxable income into the costs used for obtaining taxable income. If this was not regulated, then the Taxable Income should not be consistent with the actual condition, so as to result in lower tax income paid by the taxpayer or to result in loss. Therefore, the government in this case had anticipated the foregoing by drawing up Article 13 of Government Regulation No. 94 year 2010 prohibiting the use of expenses related to non-taxable income as deductible expenses.

\section{CONCLUSION}

The argumentation used by the DJP in applying tax treatment to PT A on the amortization expenses of goodwill resulting from acquisition had not been in accordance with the applicable accounting and taxation provisions. In the accounting provisions, the goodwill of PT A originating the acquisition of PT B and PT D should remain existing following the merger of PT B and PT D to PT A; in taxation provisions, the amortization expenses of goodwill of PT A should remain be expenses for tax purpose as they constitute charges for obtaining, collecting, and maintaining Taxable Income.

Tax treatment on the amortization expenses of goodwill of PT A applied by the DJP had not fully fulfilled the legal certainty principle. First, from the aspect of formal law certainty, the DJP had not trusted the financial statements of PT A audited as fixed bases for calculating outstanding tax as regulated in the elucidation on Article 
28 paragraph (7) of the General Tax Provisions and Procedures Law; second, from the aspect of material legal certainty, legal certainty on income tax object also had not been fulfilled due to the continuously existing difference in the acknowledgement of amortization expenses of goodwill of PT A as deductible expenses for tax purpose. This had resulted from the occurring difference in the interpretation of Article 13 of Government Regulation No. 94 year 2010 related to the amortization expenses of goodwill of PT A as costs for obtaining non-taxable income. The DJP had interpreted the article grammatically while PT A had interpreted the Article logically and historically.

Based on the problems found, there had been a number of suggestions and recommendations for PT A and the DJP. First, to avoid different opinions between the taxpayer and the DJP in relation to the accuracy and the fairness of the taxpayer's financial statements, therefore the DJP had been suggested to provide training or special training to the tax auditor to understand the FAS applicable in Indonesia so as to create similar understanding between the tax auditor and the public accountant; Second, in order to strengthen the argumentation of PT A to the DJP that the amortization expenses of goodwill of PT A were not costs for obtaining non-taxable income in the form of dividends as regulated in Article 13 of Government Regulation No 94, PT A must be able to indicate strong and concrete evidences that the occurrence of goodwill of PT A had actually affected the Taxable Income of PT A. Whereas the aforementioned evidence among others could be in the form of increased Article 25 Income Tax of PT A following business restructuring and business purpose documents when conducting business restructuring activity; Third, in order to achieve the formal legal certainty principle, in audit inspection, the DJP had been suggested to acknowledge the audit report drawn up by the Independent Auditor as valid report for calculating the Taxable Income of PT A. Thereby, there had not been any different opinions between PT A and the DJP in respect of the Taxable Income of PT A; Fourth, in order to avoid the occurrence of different legal interpretations on the provision of Article 13 of Government Regulation No. 94 year 2010, directive or additional regulation on how far the provision of Article 13 of Government Regulation No. 94 year 2010 can be applied should be given to the taxpayer. This could be conducted by providing conditions that must be fulfilled by the Taxpayer such as the objective and custom of the occurrence of charges or expenses, increased Corporate Income Tax minimum for the past 3 years, and projected increase in the company's and group’s profits for the next 5 years.

\section{REFERENCES}

[1] D. E. Kieso, J. J. Weygandt, T. D. Warfield. Intermediate Accounting, John Wiley \& Sons, Inc, Hong Kong (2011).

[2] E. Hidayanti, Sunyoto. Amortisasi goodwill. Jurnal WIGA, 2(1)(2012) 18-23.

[3] H. S. De Leon. The fundamental of taxation. Rey Printing Company Inc, Manila (1997) 165.

[4] Gunadi. Akuntansi pajak (sesuai dengan undang-undang pajak baru), PT Grasindo, Jakarta (2009).

[5] V. Thuronyi. Tax law design and drafting, International Monetary Fund, Washington D.C., 2 (1996).

[6] L. Yudkin. Tax technique handbook: a legal structure for effective tax administration, International Tax Program Harvard Law School, Cambridge (1971).

[7] R. M. Sommerfeld. An introduction to taxation, Harcourt Brace Javanovich Inc, London (1982).

[8] R. Soemitro. Pajak ditinjau dari segi hukum, Eresco, Bandung (1990).

[9] S. Mertokusumo. Bab-bab tentang penemuan hukum. Yogyakarta: PT Citra Aditya Bakti, In partnership with Konsorsium Ilmu Hukum Departemen Pendidikan dan Kebudayaan and The Asia Foundation, (1993).

[10] W. L. Neuman. Social research methods: qualitative and quantitative approaches, Pearson Education Inc, United States of America, (2003) 76. 